\title{
THE STUDY OF THE BIBLE IN THE MIDDLE AGES
}

By BERYL SMALLEY

Demy 8vo.

Fellow of St Hilda's College, Oxford

About 320 pages Cloth

About 35s. net

\section{CROWN, COMMUNITY, AND PARLIAMENT}

IN THE LATER MIDDLE AGES

By GAILLARD T. LAPSLEY

Sometime Fellow of Trinity College, Cambridge

Edited by HELEN M. CAM and GEOFFREY BARRACLOUGH Demy 8vo. Cloth

\section{AN INTRODUCTION TO THE} STUDY OF ECCLESIASTICAL LATIN By H. P. V. NUNN, M.A. St John's College, Cambridge

Third Edition Cr. 8vo. 228 pages 7s. $6 d$. net

NAPOLEON BONAPARTE: HIS RISE AND FALL By J. M. THOMPSON, F.B.A., F.R.Hist.S. Honorary Fellow of Magdalen College, Oxford

Demy 8vo. Cloth

\section{A SHORT HISTORY OF THE FRANCHISE IN} ENGLISH LOCAL GOVERNMENंT By B. KEITH-LUCAS Faculty Fellow of Nuffield College Demy 8vo. Senior Lecturer in Local Government in the University of Oxford About 27s. 6d. net WITH MILNER IN SOUTH AFRICA BY LIONEL CURTIS

Second Edition Cr. 8vo. Cloth 20s. net

\section{A BREVIATE OF}

PARLIAMENTARY PAPERS I917-1939 Edited by P. FORD

Professor of Economics, University College, Southampton

Royal 8vo. Cloth f2. ros. net 


\section{EDINBURGH}

\section{THE GOLDEN AGE}

MICHAEL JOYCE

A fascinating picture of the social life and personalities of Edinburgh in the days of such men as Hume, Adam Smith, Mackenzic, Burns, Jeffrey, Sydney Smith, Raeburn and Scotta time when it was said, if one stood for a few minutes at the Cross, one might take fifty men of genius by the hand.

The book is a fitting record of the distinguished part which the Scottish capital played in the history of European culture.

18s. net

\section{THE MAHDIYA}

\section{A HISTORY OF THE}

\section{ANGLO-EGYPTIAN SUDAN, 1881-1899}

\section{A. B. THEOBALD}

To-day, when Britain's relationship with the Middle East is in a state of change and development, it is particularly timely that a book should be published which tells how she came to be responsible for the administration of one of the largest countries of that area, the Anglo-Egyptian Sudan.

' $\mathrm{Mr}$ Theobald approaches his subject with the double, and unusual, advantages of a thorough knowledge and sympathetic understanding of the Sudan and the techniques and background of a trained academic historian.'-Times Literary Supplement.

21s. net

\section{HUSKISSON AND HIS AGE}

\section{Volume One}

\section{R. FAY}

'The volume, with its numerous extracts from family letters and papers, has the fascination and the amusing quality of a first-rate book of memoirs. No one who is interested in the politics and the social background of that age, when this country was gathering to herself the leadership of Europe, can afford to miss it.' -Prof. W. H. B. Court in Birmingham Post.

30s. net

\section{LONGMANS}

\section{6 \& 7 CLIFFORD STREET, LONDON, W.1}

